\title{
Local cooperation for innovation. \\ Food and beverage multinationals in a peripheral European country
}

\author{
Antonio García Sánchez \\ Lecturer of Applied Economics \\ Universidad de Sevilla \\ Avenida Ramón y Cajal, 1 \\ 41018 Sevilla, Spain \\ acichez@us.es \\ José Molero \\ Professor of Applied Economics (Chair) \\ (Universidad Complutense de Madrid, Spain) \\ imolero@icei.ucm.es \\ Ruth Rama (1) \\ Research Professor \\ IEGD-CSIC \\ Albasanz, 26-28 \\ 28037 Madrid, Spain \\ ruth.rama@cchs.csic.es
}

(1) Corresponding author

Professor Antonio García Sánchez is Lecturer of Applied Economics at the Department of Economics and Economic History (University of Seville, Spain). He won his PhD degree in Economics from the University of Huelva. He is a member of the research groups "Economic Analysis and Political Economy" (University of Seville) and "Economics and Politics of Innovation and Technical Change" (Complutense Institute of International Studies). His main research interests are in the economics and policy of innovation (theory and micro-econometrics); cooperation for innovation, internationalization and regional distribution of innovation activities and the relationships between culture, creativity and innovation. He has published in peer-reviewed journals such Science and Public Policy, Technovation, Estudios de Economía Aplicada, Información Comercial Española, and Economía Industrial.

Professor José Molero is Professor of Applied Economics at the Universidad Complutense de Madrid (UCM), Director of the Research Group on Economics and Politics of Innovation, and President of the Innovative Firms Forum. He won his PhD in Economics at the Complutense University. He was formerly Vice Rector of Postgraduate Studies and Continuing Education; Director of the Complutense Institute for International Studies, and Head of the Department of Applied Economics at UCM. He is an assessor for several Spanish and international institutions, such as the European Commission and the European Institute of Technology and Innovation, the Spanish Ministries of Economy and Industry, and most Spanish Regional Governments. He has published in national and international journals, such as Research Policy, Technovation, Science and Public Policy, Structural Change and Economic Dynamic, the European Journal of Innovation Management and World Patent Information. His main areas of interest are: Industrial Economics, Economics of Technical Change, Transnational Corporations, and Industrial Policy.

Professor Ruth Rama is a tenured Research Professor at the Institute of Economics, Geography and Demography of the Spanish National Research Council (CSIC). She has a PhD degree from the Autonomous University of Barcelona. Her main research interests are in multinational enterprises and their interplay with national innovation systems; networks of innovators, and location of the R\&D activities of firms. She has published in international journals such as Environment and Planning A, Urban Studies, Technovation, Journal of Technology Transfer, International Journal of Technology Management, Science and Public Policy, European Planning Studies and Industry and Innovation.

Acknowledgements. The authors thank two anonymous referees for useful comments and suggestions on a previous version of this article. Ruth Rama also gratefully acknowledges support from project ECO2014-52268, Ministry of Economy and Competitiveness (Spain), and European Union ERDF funds.

Published in: Int.J.of Multinational Corporation Strategy, vol 1, no.2, 107-132 (2016) https://www.inderscience.com/info/inarticle.php?artid=79449 


\begin{abstract}
We performed econometric analysis to identify some of the main features of food and beverage foreign subsidiaries engaged in local R\&D cooperation. In Spain, their main contributions to local networks of innovators seem to be financial and commercial rather than technological. Foreign subsidiaries that display high R\&D intensity, and have a large number of R\&D employees or a large share of new products in turnover, are not necessarily engaged in local R\&D networks. Foreign subsidiaries facing fewer obstacles to innovation than the average food and beverage firm seem better able to build those networks. The most important features of food and beverage multinationals that cooperate for innovation with local partners are those of economic strength and dominant market position. Foreign subsidiaries appear to combine internal and external information in order to innovate. Their size or their export activities are not significantly associated with a possible involvement in local cooperation for innovation.
\end{abstract}

(F23, L66, O33)

Key words: food and beverage MNEs; internationalization or corporate R\&D; FDI in R\&D; cooperation for innovation with local partners; networks of innovators; Spain; peripheral European countries. 


\section{Introduction}

Host countries are now competing to attract high-quality foreign direct investment (FDI), that is, innovative companies, and R\&D FDI, since policy makers believe that these companies may transfer technology to local industries (Guimón, 2011). However, many FDI schemes are unlikely to fulfil all, or even most, of policy-makers' expectations with regard to the development of national industrial capabilities (McCann \& Mudambi, 2004). Foreign subsidiaries (hereinafter, FS) may remain isolated, generating a "branch plant syndrome". International organizations suggest that foreign companies that establish local networks with institutions and other companies are more likely than isolated multinational enterprises (MNEs) to contribute towards the upgrading of national industries (UNCTAD, 2001). One such linkage is cooperation for innovation with local partners ${ }^{1}$.

With the publication of the Community Innovation Surveys (CIS) of the European Union (EU), several cross-sectional studies have focused on the influence of foreign ownership on local cooperation for innovation. Certain studies suggest that FS operating in different host industries may display different cooperative strategies (Ebersberger et al., 2011; García Sánchez et al., 2015). (The term cooperative refers in this article to engagement of the firm in R\&D cooperation). However, very little is known about the possible effects of foreign ownership on cooperation for innovation in traditional industries since, as mentioned above, most studies on this topic are cross-sectional. On the other hand, the literature on open innovation focuses mainly on high-tech sectors (Mortara \& Minshall, 2011). It has been claimed that firms in these sectors are more prone to cooperating for innovation since they face riskier and costlier innovation processes; therefore, the argument goes, cooperation may allow them to share costs and enter new technological fields (Carboni, 2013; Ebersberger et al., 2011; Miotti and Sachwald, 2003). In contrast, the cooperative strategies of FS in traditional sectors have been overlooked by the empirical literature.

The aim of this article is to contribute towards filling this gap. There are several reasons for specifically studying the strategies of F\&B multinationals. 
Firstly, MNEs are not a homogeneous group. Compared to non-food MNEs, F\&B multinationals display peculiarities concerning innovation, and this circumstance may affect their R\&D cooperation patterns. Therefore, the analysis of these companies may contribute towards a more detailed knowledge of the cooperative activities of MNEs in host countries. Secondly, there are also major practical reasons for their analysis. The F\&B industry is the largest EU-27 manufacturing industry in terms of value-added and employment, as well as a major source of export revenues ${ }^{2}$. The innovative role of foreign multinational enterprises (MNEs) is important in the F\&B industry. The share of foreign affiliates in R\&D in food, beverages and tobacco is over $40 \%$ of the national total in the industries of OECD countries, such as Germany, Portugal, Sweden and the United Kingdom ${ }^{3}$. Moreover, all over the world, the largest F\&B multinationals contribute a substantial part of the patented inventions available to this industry and, in general, to the food chain (e.g. agriculture) (Alfranca et al., 2002). This suggests that cooperation with F\&B subsidiaries may contribute, in theory, towards extending the innovative capacities of the national innovation system (NIS) in host countries. Furthermore, domestic firms may have technological capabilities, but may lack complementary assets (Teece, 1986) and financial resources that would otherwise have enabled them to commercially exploit their new ideas. Foreign subsidiaries may eventually contribute towards providing such resources. These questions are especially relevant in peripheral European countries and probably in certain emerging economies. These countries often present limited absorptive capacity in hightech sectors, but may present absorptive capacity in traditional sectors. This circumstance may facilitate transfers of technology to their traditional sectors. The case of Spain, which is analysed here, is of interest for several reasons. Although the share of R\&D in F\&B production in Spain is clearly below that in other EU producing countries, such as Finland and Denmark (Wijnands et al., 2008), the Spanish F\&B industry displays revealed technological advantages (RTA) (Molero \& García, 2008). Moreover, Spain is a competitive food producer (Wijnands et al., 2008). This suggests that firms operating in this industry, as well as local institutions, enjoy an absorptive capacity concerning food science and technology (Cohen \& Levinthal, 1989) and may potentially benefit from the presence of highly innovative food and beverage FS. At the 
same time, Spain is one of the most important European receivers of FDI, and its F\&B industry seems to be an attractive target for foreign $\mathrm{MNEs}^{4}$. The situation may be similar in other peripheral European countries and even in certain emerging economies that are also competitive food producers and substantial receivers of agro-food FDI. Being substantial receivers of food and beverage FDI, they may also expect to link their NIS to international flows of knowledge via FS; hence, the interest in an in-depth analysis of the Spanish case.

Here, we ask whether quality food and beverage FDI is likely to be involved in R\&D cooperation with local partners in Spain. For the first time, to the best of our knowledge, hypotheses about the local patterns of R\&D cooperation of food and beverage (hereinafter, F\&B) multinationals are tested with data which are representative of a national industry. Our ultimate objective is to understand whether foreign $F \& B$ multinationals are likely to make a contribution to domestic innovative capabilities. Therefore, we are especially interested in FS displaying above-average intensity of innovation. Foreign subsidiaries showing this characteristic hold particular importance from the point of view of a catching-up country, since non-innovative FDI may contribute little in terms of new knowledge and, instead, crowd out domestic firms (Buckley et al., 2007).

This article contributes towards the currently scarce literature on R\&D cooperation between foreign subsidiaries and local partners at the two-digit industry level. In doing so, it shows that the local cooperative strategies of these companies display specificities that depend on the peculiar characteristics of innovation and the particular factors, both technical and structural, that shape local R\&D cooperation in a two-digit industry. This constitutes a contribution towards the analysis of heterogeneity in the local R\&D cooperation patterns of MNEs. Our research contests the idea that the presence of highly innovative FS may imply substantial transfers of technology to the NIS via cooperation with local partners. It suggests, instead, that food and beverage FS enjoying financial and commercial strength, though not necessarily technological strength, may be contributing economic resources and marketing skills to local innovative networks. 
Section 2 presents the literature review and our hypotheses, Section 3 the methodology, and Section 4 the results of the econometric analysis and the discussion. Section 5 concludes.

\section{Literature review and hypotheses}

In what follows, we discuss and integrate findings and interpretations of the international business (IB) literature, the literature on $R \& D$ cooperation and networks, and the literature on innovation in the F\&B industry. These various strands of literature inform the formulation of our hypotheses.

\subsection{Innovation in the F\&B industry}

On a global level, innovation has become a must for the F\&B processing industry as a result of saturated demand in terms of volume in industrialised countries, the need to produce more food for a growing world population, changing consumer tastes, and current awareness about sustainability problems of modern food production. A major challenge faced by the industry and especially by F\&B multinationals comes in the form of criticism related to health issues (Moodie et al., 2013). Science and technology may also help to boost production at lower prices and to develop new methods to deal with waste (Acosta et al., 2011). Food and beverage companies source new technology from an increasing variety of agents, such as supermarkets, auxiliary industries, and universities (for a review of the literature, see Rama \& von Tunzelmann, 2008). Although the F\&B industry is often depicted as a traditional industry, nowadays it utilizes a broad spectrum of sciences and techniques (e.g. biotechnology, informatics, scientific instruments) (Christensen et al., 1996). Although the share of food inventions constitutes the largest proportion of the total patented inventions available to the F\&B industry, there are also a substantial number of inventions of upstream industries, especially for commodity-type food industries (Rama, 1996). Analysing European Patent Office (EPO) patents, Acosta et al. (2013) observe that the most important sources of external technological knowledge used for food inventions from 1998-2006 were the mechanical and machinery engineering sector, process engineering and equipment, and chemistry and pharmaceuticals. Often interacting with their suppliers, the world's largest F\&B multinationals have 
reorganized their internal R\&D activities to profit from knowledge provided by auxiliary industries, notably the chemical, pharmaceutical and biotechnology industries (Alfranca et al., 2004).

Multinational enterprises play an important role in this new scenario of innovation: the world's 100 largest food and beverage MNEs patent around $50 \%$ of the inventions available worldwide for food and drink processing, agriculture, and auxiliary industries (Alfranca et al., 2002). As summarised by Tozanli (2005, p. 26), within this group of firms, "the most dynamic and innovative MNES won over those that placed their competitive advantages merely on raw material procurement". However, while the share of their patents in total food-related inventions is substantial, the actual core number of highly innovative F\&B multinationals is rather small; most are not innovative (Alfranca et al., 2002).

$R \& D$ cooperation is becoming increasingly important in this industry. Spanish agro-food firms are more cooperative than the average Spanish firm (Bayona-Sáez et al., 2013). Worldwide, F\&B firms also present increasing interest in partnerships for innovation (García Martínez, 2013a; Omta et al., 2014; Senauer \& Venturini, 2005). R\&D in the food industry has become quite expensive; a new circumstance which seems to encourage collaboration for innovation, as in other sectors (García Martínez, 2013a). Certain case studies report that several very large F\&B multinationals, such as Danone, Kraft, Nestlé and Unilever, have been engaged in collaboration and other practices of open innovation (e.g. outsourcing of R\&D services), especially since 2000 (García Martínez, 2013a; Mortara \& Minshall, 2011). The focus of most of these case studies is on the cooperative activities of the headquarters or of the world R\&D centres of the F\&B multinationals. In contrast, we are interested in the cooperative activities of these companies in their host countries.

The literature on innovation in the F\&B industry shows that non-food inventions are gaining importance in the production of processed F\&B. The management literature notes, in turn, that the headquarters and the world R\&D centres of major F\&B multinationals are becoming further engaged in cooperation for innovation and other practices of open innovation with companies and institutions external to the multinational business group. In our view, both phenomena may be related, since one of the reasons for $R \& D$ 
cooperation is the current importance of inter-sectoral technology (Hagedoorn, 1993).

\subsection{Foreign status and local cooperation for innovation}

This sub-section discusses research results of the general literature on MNEs, and those of the literature specifically on F\&B multinationals.

For the MNE, the decision to cooperate with local partners depends on a variety of factors, such as the degree of internationalization of its R\&D activities, its sector, the technological competences of the host country, and the liability of foreignness faced by the multinational. Multinational enterprises perform R\&D abroad for reasons such as: learning from foreign lead markets or lead customers; adapting their products to local regulations or ingredient availability; accessing the NIS; and using publicly funded R\&D available in the host country (Edler, 2008). Large F\&B companies display high rates of internationalization of assets, sales, and employment (Senauer \& Venturini, 2005). As shown by patent analysis, large F\&B multinationals are now performing an increasing share of their innovative activities in foreign countries (Rama \& Martínez, 2013). Cultural aspects are especially relevant concerning F\&B consumption and, in spite of trends toward homogenization in Western countries, differences in local tastes remain significant. Consequently, F\&B multinationals are more prone than other multinationals to internationalization of their R\&D activities (Cantwell \& Janne, 2000), since they need to adapt their foodstuffs to various national tastes.

Foreign direct investment in R\&D has been increasingly aimed at tapping into local fields of expertise (Cantwell \& lammarino, 2000). Flows of two-way knowledge between FS and domestic firms are substantial, especially in developed countries, and that outflows are greater in sectors where the host country displays stronger technological capabilities (Singh, 2007). A study shows that FS benefit from reverse spillovers coming from: domestic companies, native MNEs, and other FS located in the same host country (Driffield et al., 2014). This research work is a departure from the traditional IB model, which assumes that new knowledge flows exclusively from the FS to the host country. It shows, instead, that new knowledge could also flow from the host country to the FS. Part of the technology needed by foreign subsidiaries is 
sourced locally through cooperative arrangements with local companies and institutions, such as universities. The literature, however, points to certain difficulties that may be encountered by the FS in host countries. The social capital of a firm, as generally understood by the economic and management literature, is equivalent to its "networking capital". The transaction cost literature has made particularly important contributions towards explaining the value of social capital for networked firms (Williamson, 1985). In a host country, FS may be lacking such social capital (Rugman \& Verbeke, 2001), and this circumstance may restrain their ability for networking locally. Several studies on the food industry argue that less tangible concepts, such as trust and power, are as important as purely economic considerations in networked innovation processes (Trienekeus et al., 2003; Omta et al., 2014).

Faced with high transaction costs, MNEs may prefer to internalise knowledge production in order to minimize the risks of involuntary spillovers (Caves, 1996). Such risks may be real when new products are relatively easy to imitate, as is the case with new foodstuffs (Gallo, 1995). Additionally, the appropriability regime in this industry does not facilitate collaboration since IP protection is often based on trade secrets (Omta et al., 2014). After analyzing $R \& D$ collaboration and other open innovation practices in a sample of European food firms, the above study warns: "when technological competencies are strong, there should be preference for in-house R\&D whenever possible", (p.29). Furthermore, spillovers are more likely when the technology gap between the foreign company and the industry of the host country is smaller (Kokko, 1994). Foreign subsidiaries operating in the F\&B industry may face this situation in catching-up countries that enjoy RTA regarding food science and technology. However, internalization strategies may promote the technological isolation of the FS in the host country.

Although there are a few exceptions (García Sánchez et al., 2015; Holl \& Rama, 2014), most cross-sectional studies find a negative effect of foreign status on local cooperation for innovation. A pan-European study reveals that foreign ownership is positively associated with international R\&D collaboration and negatively associated with domestic R\&D collaboration (Ebersberger et al., 2011). In the view of these authors, international linkages of FS may occur at the expense of domestic linkages. Furthermore, the literature suggests that, 
within the EU, poor embeddedness of FS is more common in countries that are not at the forefront in science and technology (Ebersberger et al., 2011; Srholec, 2009 and 2015).

There is only limited quantitative evidence that specifically concerns the possible effects of foreign ownership in the F\&B industry. Analysing data for Mexico, Kokko (1994) found that FS may operate as enclaves in industries of a monopolistic nature where the competitive assets of these companies were likely to consist of superior market abilities, as well as brand names and labels; for instance, the presence of FS was not likely to produce spillovers in Mexican industries, such as those of beverages, instant coffee, and prepared foods. Analysing Spanish data, Guimón \& Salazar-Elena (2015) found that, in the food, beverage, and tobacco industry, FS are less prone to cooperating for innovation with local universities than domestic firms. In a sample of Czech firms operating in the food and tobacco industry, foreign ownership decreased the probability of international R\&D cooperation by $74 \%$, but had no effect on the probability of domestic cooperation (Knell \& Srholec, 2005). In contrast, a case study on a foreign chocolate MNE in Italy suggests intensive collaboration for innovation between the company and local partners (Lazzarotti \& Manzini, 2013). The available evidence is inconclusive concerning the possible influence of foreign status on local cooperation in the F\&B industry: hence the interest of the present study.

The literature suggests that two divergent driving forces may influence the cooperative strategies of F\&B subsidiaries. As compared to non-food FS, food and beverage FS are more likely to internationalize their R\&D activities and to heavily depend on local information for the adaptation of their products to the local demand. In theory, this driving force may induce food and beverage FS to cooperate with local partners, especially when the host industry may provide them with new knowledge. However, these FS face greater risks of involuntary spillovers, especially if the potential partner enjoys absorptive capacity, and if rival domestic firms and other MNEs operate in the host industry. This second driving force may have an opposite, negative effect on their willingness to cooperate for innovation with partners external to their own business group. 


\subsection{Innovative firms and R\&D cooperation}

As stated earlier, host countries currently display an unambiguous preference for R\&D-intensive FDI since policy-makers believe that these companies may transfer technology to the domestic economy (Guimón, 2011). Several cross-sectional studies suggest that R\&D-intensive FDI is indeed likely to engage in local cooperation for innovation. In a sample of non-European MNEs operating in Spain, Álvarez and Cantwell (2011) found that those defined as "innovators" in the study, that is, exporters that had introduced products new to the market, are likely to engage in local R\&D cooperation. In a sample of innovative FS of all nationalities operating in Spain, a high value of total innovation expenditures predicts R\&D cooperation within the same business group but not necessarily with local partners external to the group, except local universities (Álvarez, 2011). In another cross-sectional study based on Spanish data (Holl \& Rama, 2014), it was found that FS performing R\&D, especially basic and applied research, were clearly more prone to cooperating locally for innovation than affiliated domestic firms (controlling for technological leadership, size, and other variables in the model). In contrast, FS that did not perform R\&D were not significantly different from affiliated domestic firms. In a sample of FS that operate in Greece, it was found that large and innovative companies are more likely to cooperate with local institutions and firms (Manolopoulos et al., 2005). Another study finds that R\&D-intensive parents tend to internationalize their innovative activities for the purpose of knowledge sourcing in host countries (Ito \& Wakasugi, 2007). The discussion tends to suggest that $R \& D$ intensity is associated to local collaboration.

However, these studies are cross-sectional, and patterns of R\&D collaboration may vary by sector (Belderbos et al., 2004; Guimón \& SalazarElena, 2015 Hagedoorn, 1993; Schmidt, 2008). A pan-European study found that innovation intensity is associated with high levels of cooperation only in high-tech sectors (Ebersberger et al., 2011).

The literature on innovation in the F\&B industry provides some guidance on how to define R\&D intensity in this specific industry. Formal R\&D intensity alone may be "unable to capture the actual relevance of product innovation in this industry" (Galizzi \& Venturini, 2008 p. 51). New foodstuffs are often generated on the shop-floor level, not in a formal R\&D department and, 
therefore, expenditures devoted to innovation are essential for F\&B firms. Resources committed to the distribution of innovations are crucial to ensure the success of new foodstuffs (Geroski \& Vlassopoulos, 1991). The world's largest F\&B multinationals combine design innovation, and innovation in product and processes (Alfranca et al., 2002); this points to the importance of expenditures in design. Analysing Spanish data, Santamaría et al. (2009) find that design, training, and the use of advanced machinery play a substantial role in the innovative processes of firms operating in low- and medium-tech industries, while formal R\&D occupies central stage in the innovative processes of companies operating in high-tech industries. They conclude that companies in low-tech and medium-tech industries "have alternative innovation sources beyond internal R\&D”, (p.514). Finally, in industrialising countries, and even in the periphery of Europe, FS may concentrate their technological efforts on aspects other than developing internal R\&D capabilities. Indeed, Franco and Quadros (2003) find that foreign F\&B firms operating in Brazil consider the acquisition of equipment to be their most important technological strategy in the host country, followed by the acquisition of disembodied technology and, only lastly, by internal R\&D activities. A comprehensive approach to the innovation resources available to food and beverage FS is therefore needed. The discussion suggests that highly innovative F\&B subsidiaries may face the risk of involuntary spillovers due to the ease of imitating foodstuffs and to the nature of the appropriability regime in this specific industry. As stated earlier, the Spanish F\&B industry has RTA, and this circumstance may imply that domestic firms and other F\&B multinationals operating in Spain enjoy absorptive capacity. Therefore, highly innovative FS may fear that cooperation with local partners could lead to involuntary spillovers of knowledge.

\subsection{Obstacles to innovation}

Cross-sectional studies have found that companies cooperate for innovation for a variety of reasons: to share costs, to reduce risks involved in $R \& D$, to shorten the product life cycle, to expand their product range, to access new knowledge and new markets, etc. (Miotti \& Sachwald, 2003; Mortara \& Minshall, 2011; Schmidt, 2008). Motives for R\&D cooperation vary across sectors (Hagedoorn, 1993; Schmidt, 2008); they may also differ in terms of type 
of partner, for instance, small and large companies (Mortara \& Minshall, 2011). Specifically, case studies suggest that the decision of small F\&B firms to cooperate for innovation with a larger partner, sometimes an MNE, often has to do with goals such as obtaining access to: a larger customer base; commercial know how or finance; and skills which enable the transformation of an idea into a profitable new product (García Martínez, 2013a). Aspects related to the commercialization of innovation seem to constitute a major motivation for these types of prospective partners. Food and beverage multinationals may also have various reasons for collaboration. In a group of six very large F\&B multinationals, a qualitative case study noted that the companies viewed open innovation as an opportunity to accelerate innovation, strengthen their respective branding messages, and access external resources and competencies (Mortara \& Minshall, 2011). These MNEs often lack "the critical mass to excel in all technological areas" (García Martínez, 2013b, p.318). To serve new niche markets, a company may need to master technologies with which it is not familiar. Furthermore, an FS may engage in local R\&D cooperation to learn new recipes from other food cultures and commercialise them all over the world (Anastassopoulos et al., 1997). Therefore, in an R\&D cooperative arrangement, the respective objectives of the FS and of local partners, especially SMEs, may be very different.

Several factors may put the brakes on the innovative efforts of a company: difficulties in accessing knowledge, insufficient technological information, etc. The literature suggests that, in the F\&B industry, market factors may have a substantial influence on innovation. Gopinath and Vasavada (1999), studying the US F\&B industry, conclude that firms exhibiting non-competitive behaviour have greater chances of achieving patented inventions than firms operating in competitive markets, because they can devote part of their monopolistic profits to innovation. In Spanish industry, Triguero et al. (2013) observe that the main difference between food and other manufacturing firms lies in the greater influence of market-related factors on innovation. In the food industry, they argue, the probability of innovating depends more on these types of aspects than on a firm's resources, such as R\&D or large plant size. 
How do obstacles to innovation affect R\&D cooperation patterns? There are two opposing answers to this question. According to the resource-based view (RBV) of the firm, obstacles may stimulate R\&D cooperation, which is seen as a solution to problems the company cannot solve by itself (Miotti \& Satchwald, 2003). For this line of theory, the insufficiency of resources leads to cooperation. The evidence, however, is not conclusive. For instance, analysing a sample of Canadian firms, Schmidt (2008) found that companies facing obstacles to innovation are more prone to cooperating if the objective of cooperation is to commercialize their new products. However, these companies were not necessarily more prone to cooperating when they pursued other objectives, such as sharing the costs of R\&D and accessing new knowledge. In contrast, the management literature on networks takes into consideration the point of view of the potential partner. Companies displaying "high technological strength and commercial assets enjoy greater facility in obtaining partners" (Ahuja, 2000, p. 339). Widespread evidence suggests that this may well be the case in the F\&B industry (Omta et al., 2014; Tripple, 2011). In our view, the fact that an FS encounters fewer obstacles to innovation than the average F\&B company signals certain key strengths of the subsidiary, and this circumstance may facilitate the recruitment of skilled local partners.

We propose that, in this specific two-digit industry, highly innovative foreign subsidiaries are reluctant to cooperate for innovation with local partners since they may fear involuntary spillovers of knowledge. Furthermore, foreign subsidiaries that face few technical, economic and market obstacles to innovate are more likely to attract local innovators than subsidiaries facing more obstacles than average. Foreign subsidiaries facing no economic and marketing difficulties in their efforts to innovate, or at least fewer difficulties than average, are likely to be especially targeted by potential local partners since, in this specific industry, innovators are unlikely to obtain profits from their inventions if they lack complementary assets. Therefore, from the point of view of local innovators, foreign subsidiaries that own these complementary assets are particularly attractive innovation partners. On the other hand, an economic or marketing contribution to a local R\&D network may enable a foreign subsidiary that is not necessarily innovative to absorb new knowledge from local 
innovators. Therefore, these foreign subsidiaries are more likely to engage in local R\&D collaboration.

To put these questions to test, we formulate the following hypotheses:

$\mathrm{H} 1$ : Innovation-intensive FS are not necessarily more likely to engage in local R\&D cooperation than non-innovation-intensive FS.

We consider innovation-intensive FS to be those displaying higher-thanaverage innovation expenditures. As suggested in the discussion, a comprehensive approach to innovation intensity is adopted (see definition below and Appendix 1). Our concern with innovation-intensive FS goes beyond mere academic motives. We are also interested in these subsidiaries for practical reasons: these companies are more likely to bring state-of-the-art technology to host countries. If an FS is not innovative, its potential to transfer useful technology to a catching-up country is obviously limited. Given the emphasis laid on linkage policies by the European Commission and by international institutions (Guimón, 2011; UNCTAD, 2001), a clear understanding of the potential benefits of such linkages for the host country is essential.

H2: Obstacles to innovation are likely to be a deterrent for local cooperation for innovation.

We measure whether the focal FS faces more obstacles concerning innovation than the average F\&B company (definitions in Appendix 1).

\section{Methodology.}

\subsection{Research environment and data}

In 2009, the FDI position of Spain in food products (inward FDI) was €9.7 $\mathrm{bn}^{5}$. To put this figure into perspective observe that, the same year, the position of Germany was $€ 3.5 \mathrm{bn}$. The subsectors that have attracted the most FDI to the Spanish F\&B industry are: beverages; bread and fresh pastries; dairy products; and dietary products ${ }^{6}$. The most important source countries are the Netherlands and France. 
Here, we used the PITEC database (a data panel based on the Spanish Innovation Survey prepared for the CIS) which provides anonymised microdata for foreign or domestic companies located in Spain. Compared to Spanish data provided by CIS surveys, PITEC enhances the dataset by ensuring the datapanel format and by providing data collected every year (CIS has a two-year periodicity). A sample of 153 observations pertaining to innovative FS operating in the Spanish F\&B industry over the 2004-2008 period was obtained, and 121 observations were selected for FS that had provided responses for every year. Therefore, a balanced panel of data is analysed. We analyse the 2004-2008 period in order to avoid possible distortions caused by the global crisis in the ensuing years, since Spain has been one of the worst hit European countries. This industry is division 15 in the CNAE93 (Spanish acronym for National Classification of Economic Activities) rev.1, corresponding with divisions 10 and 11 in NACE rev.2. This is sector 02 in the PITEC classification. Foreign subsidiaries are defined here as companies where foreign capital accounts for at least $50 \%$ of total capital. It should be borne in mind that non-innovators are not included in our sample, since PITEC poses the question about R\&D cooperation only to firms defined by the questionnaire as "innovative", that is, companies which, in the two years prior to the survey, had done at least one of the following: launched new products into the market, introduced new industrial processes and had ongoing innovative activities, or had abandoned such activities during the two years prior to the survey. Consequently, $92.2 \%$ of the F\&B firms surveyed by PITEC (and $93.8 \%$ of the food and beverages FS) are considered innovative in this sense. The sample approximates the population of FS operating in the Spanish F\&B industry that were innovative, in this broad sense, during the period.

We perform a logistic regression in which the dependent variable (domRDcoop) indicates whether the focal FS was engaged in cooperation for innovation with local partners in the two years previous to the survey. According to the PITEC questionnaire, cooperation for innovation consists of the active participation of the focal firm in innovative activities carried out with other companies or with institutions; mere subcontracting of R\&D services is excluded. Estimations were calculated with inferences based on panel robust standard errors. See equation below: 


$$
P\left(\text { domRDcoop }=1 \mid X_{i}^{T}, \beta^{T}, \alpha_{i}\right)=\Lambda\left(\alpha_{i}+\beta^{T} X_{i}^{T}\right)
$$

\subsection{Variables}

The variables are presented below and fully defined in Appendix 1.

\subsubsection{Dependent variable}

domRDcoop (cooperation with local external partners in the two years previous to survey). Our dependent variable is a dummy indicating whether the focal FS cooperated for innovation with external partners located in the host country. "External" refers here to partners which are not part of the multinational group, such as other FS, Spanish business groups, independent companies and institutions located in Spain (description of variable in Appendix 1).

\subsubsection{Independent variables}

It should be stressed from the outset that all our independent variables denote intensity as compared to the F\&B industry (including both domestic and foreign firms); for instance, above average innovation expenditures, above average size and so on. With this methodology, we aim at defining the features and capabilities of the host industry. Our objective is to understand the FS' degree of embeddedness when characteristics of the host industry are controlled for. Intensity is indicated by an " $i$ " before the name of the variable.

i_innovExp (intensity in innovation expenditures, as compared with F\&B industry average). This is our independent variable of interest since our aim is to understand whether quality food and beverage FDI is likely to be involved in local R\&D cooperation. Following the discussion (sub-section 2.3), we adopt a comprehensive approach to innovation expenditures, beyond internal formal R\&D activities. We calculate an aggregated variable to approximate all the possible contributions of FS to cooperative relationships with local partners. The aggregated index includes the following types of expenditures incurred by the focal FS: internal R\&D expenditures, external R\&D expenditures, external knowledge acquisitions for innovation (e.g. licences); technology acquisition (e.g. machinery); training expenditures; innovation expenditures; and expenditures for preparing and distributing innovations. For descriptions of 
each of these types of expenditures see Appendix 1. The selection of the variables measuring innovation expenditures is in accordance with the criteria of the Oslo Manual to determine the scale of innovative activities (OECD/Statistical Office of the European Communities). PITEC reports the amounts in Euros spent by each firm for each different type of expenditure. We compare this with the respective amounts spent by the average F\&B firm, domestic or foreign. Then, we calculate an aggregated index of intensity with values from 0 to 7 . When the value of the intensity variable is 0 , this means that the focal FS displays below average rates for all types of innovation expenditures. By contrast, if the intensity variable is 7 , the FS reports above average expenditures for all of these seven categories. We use $i$ innovExp to test for $\mathrm{H} 1$.

i_RDpers (number of employees involved in internal R\&D, as compared to industry average). This dummy variable denotes whether the focal FS hires more R\&D personnel than the average F\&B company. It measures an innovation input and may be useful for a robustness check. Moreover, following Cohen and Levinthal (1989), the variable indicates whether the focal FS enjoys more absorptive capacity than the average F\&B company -- a crucial consideration for a firm attempting to benefit from R\&D cooperation.

i_new (share of new or improved products in turnover compared to industry average). This is, in contrast, a variable measuring innovation output. A study finds that, in Spanish low-tech sectors, FS which are engaged in cooperation (domestic, international or both) are not necessarily more likely to launch new products into the market (Fernández Sastre, 2012). Focusing specifically on the Spanish F\&B industry, Bayona-Sáez et al. (2013) find similar results, with the important exception of radical innovators. Here, we calculate a variable which indicates the sales of new to the firm innovations as a percentage of the focal FS's total turnover; then, we calculate whether this percentage is above that of the average company in the Spanish F\&B industry. i_RDpers and i_new are useful variables to help us understand whether quality F\&B FDI is likely to embark on local cooperation for innovation.

i_intinfo (FS' s perception about the usefulness of internal information for innovation as compared to the average F\&B firm's perception). The IB literature suggests that innovative FS are likely to combine their own knowledge with 
local knowledge obtained in host countries (Cantwell, 2009). The management literature seems to confirm that, more specifically, cooperative F\&B companies follow the same strategy. Large F\&B firms involved in successful R\&D collaborations have often i) reorganised internally; ii) built an interface for working with external partners; and iii) promoted a collaboration culture (García Martínez, 2013b). Here, the variable denotes the perception of the FS regarding the usefulness of internal information coming from both the company itself and the multinational group for its own innovative activities. The perception of the FS is compared to that of the average F\&B company regarding its own internal sources of information. When the value for the variable is 1 , the FS has a higher-than-average opinion about the usefulness of its internal sources.

i_ownfund (share of own resources in the total resources used by the focal FS to finance R\&D, as compared to industry average). Cross-sectional studies are not conclusive as to whether credit rationed firms or firms facing high costs of innovation are more likely to become involved in cooperative arrangements (Carboni, 2013; López, 2008; Miotti \& Satchwald, 2003). Our variable indicates the share of own resources of the focal FS (credits included) in total resources used to finance internal R\&D. As in the case of the other independent variables, we calculate whether the FS's availability of own funding for innovation is above that of the average F\&B firm.

Obstacles to innovation. We take into account 11 obstacles to innovation (see Appendix 1). The obstacles were aggregated through factor analysis and re-codified into four categories: knowledge, economic, market and competitive obstacles. Then, we compared the focal FS and the average F\&B firm; when the value for the variable is 1 , the focal FS encounters higher obstacles to innovation than those faced by the average F\&B company. In the econometric model, our independent variables for obstacles are i_knowobst, i_econobst, i_marketobst and i_competobst ; respectively, knowledge, economic, market and competitive obstacles as compared to sectoral average. Interestingly enough, in factor analysis, insufficient market information clustered statistically with variables denoting, on the part of the FS, insufficient availability of qualified personnel, insufficient technological information and difficulties in accessing knowledge. It might, therefore, be assumed that knowledge obstacles to 
innovation depend not only on the FS facing technical difficulties but also on whether it has enough information about the market. We use the variables to test for $\mathrm{H} 2$.

Following cross-sectional studies on R\&D cooperation (Ebersberger et al., 2011; Holl \& Rama, 2014; Miotti \& Satchwald, 2003), we control for the size and export activities of the company.

\subsection{Descriptive statistics}

FS account for $8.4 \%$ of the F\&B companies surveyed by PITEC.

Around $29 \%$ of the sample FS cooperate for innovation with local partners. Around $64 \%$ of the sample FS report average or below average innovation expenditures; put differently, most of them are not innovation-intensive. Furthermore, $56 \%$ of the FS engaged in R\&D cooperation with local partners are less innovative than the average F\&B company in the host country.

The correlation matrix is displayed in Appendix 2. Some of the variables show moderate correlation. For instance, the FS which have more financial resources of their own to fund their $R \& D$ activities compared to the average company (i_ownfund) tend to hire more R\&D employees than the average company (i_RDpers). However, variables do not correlate too highly and no serious problems of multicollinearity were detected.

\section{Results and discussion}

The Wald chi $^{2}$ has a Prob $=0.000$ both for a model including all the independent variables (available upon request) and for the restricted model including only the statistically significant independent variables (Table 1). This suggests that our model is adequate for explaining the influence of the selected variables concerning differences dealing with local R\&D cooperation among food and beverage FS. On the other hand, the likelihood-ratio test of rho=0 $($ Prob $=0.000)$ and estimations of rho (around 99\%) suggest that the variance concerning the propensity to cooperate locally may be attributable to characteristics of firms that are not controlled for by our variables, for instance, the personality of managers. This result was expected since our definition of intensity compared with the industry average eliminates fixed industrial effects. 
Table 1 presents the results of the econometric analysis; as stated, it includes only the variables with statistically significant coefficients.

The coefficient for i_innovExp (intensity of innovation expenditure) is not statistically significant. Foreign subsidiaries that devote more money than the average F\&B firm to many different types of innovation-related investments are not necessarily prone to cooperating with local partners. By the same token, the coefficients of the two other variables which approximate an outstanding technological endowment of the subsidiary, i_RDpers and i_new, are not statistically significant. Those FS intensive in R\&D personnel or in new products are not necessarily prone to cooperating for innovation with local partners. Our results provide substantial verification of $\mathrm{H} 1$ (Innovation-intensive FS are not necessarily more likely to engage in local R\&D cooperation than noninnovation-intensive FS). They seem to confirm the view held by the IB school that MNEs would tend to avoid spillovers of knowledge and probably internalise their most important innovative activities (Caves, 1996). However, our results differ from those found by several cross-sectional studies, which observed that innovative FS are especially prone to cooperating (sub-section 2.3). Several interpretations for our result are possible. Firstly, the sample FS may follow a market-oriented strategy that is focused on exploiting their companies' capabilities rather than on augmenting such capabilities locally. Some crosssectional studies on FS operating in Spain actually suggest that asset-exploiting FS tend to cooperate with local partners to a lesser extent than asset-seeking FS (Álvarez \& Cantwell, 2011; Holl \& Rama, 2014). Secondly, as shown by descriptive statistics, the involvement of non-innovation-intensive foreign companies in local R\&D collaboration arrangements is substantial. In a national industry endowed with RTA, as is the case of the Spanish F\&B industry, this might suggest the presence of reverse spillovers - at least in specific subsectors. However, this speculative idea cannot be tested with our data. Finally, ease of imitation and appropriability regime may induce divergent cooperative strategies in F\&B subsidiaries and in FS operating in other sectors. In the latest sectors, inventions may be difficult to imitate and IPR may be better protected than in the F\&B industry. These circumstances may induce MNEs operating in different sectors to adopt different patterns of R\&D cooperation. 
Results for $i \_n e w$ are in line with those of Bayona-Sáez et al. (2013) and Fernández Sastre (2012).

i_ownfund displays a positive and statistically significant coefficient, the largest coefficient in our model (Table 1). Foreign subsidiaries that have a larger share of own funding for innovation at their disposal than the average F\&B company have more possibilities to build local networks of innovation than FS that have a smaller-than-average share. Innovation projects with external partners are often in competition with in-house projects (Omta et al., 2014). Logically enough, FS enjoying above-average financial resources of their own for innovation may be more likely to cooperate with local partners.

The coefficient for internal information (i_interninfo) is also positive and statistically significant (Table 1). Foreign subsidiaries that value their internal sources of information tend to perform local R\&D cooperation. This finding suggests that FS combine internal knowledge and local knowledge, as proposed by IB theory (Cantwell, 2009). Following the management literature (García Martínez, 2013a; Tepic et al., 2013), our result may imply that FS involved in local R\&D cooperation have put organizational innovations in place to align internal and external capabilities. Furthermore, note the association between i_interninfo and i_RDpers (Appendix 2). A relatively large R\&D department does not influence, "per se", whether an FS will cooperate with local partners since, as stated, the coefficient of $i \_R D p e r s$ is not significant (Table 1). However, the descriptive statistics suggest that once a company decides to cooperate, a large R\&D department may be a useful transmission belt, facilitating the combination of knowledge coming from both local external partners and from the rest of the multinational network.

The coefficient of $i$ marketobst is not statistically significant. The three remaining variables denoting obstacles have negative and statistically significant coefficients: i_knowobst, i_econobst, and i_competobst. These variables display the second-highest coefficients, after that of the i_ownfund variable (Table 1). Foreign subsidiaries not facing knowledge, economic or competitive obstacles to innovation, or facing them to a lesser extent than the average F\&B firm, seem better prepared to launch local R\&D collaboration networks. $\quad$ _econobst displays the largest negative coefficient of the obstacle variables. Foreign subsidiaries facing fewer-than-average difficulties concerning 
the funding of innovation, as well as those incurring lower-than-average innovation costs, have greater chances of embarking on local R\&D collaboration. In this connection, our previous results concerning the i_ownfund variable need to be recalled. The possession of substantial economic strength to finance innovation seems an important feature of food and beverage FS that perform local R\&D cooperation in Spain.

Several different explanations may help to account for findings regarding i_competobst. The possession of market power may provide companies with financial resources to build local networks around meaningful common projects. Following IB theory, the search for reliable local partners may be costly for FS because foreign companies often lack social capital (sub-section 2.2). Moreover, market position is often related to the possession of power within a network of firms (Easton, 1992). Those F\&B multinationals enjoying advantaged market positions may be less reluctant to cooperate locally since the possession of power is likely to facilitate control over the innovative network; as a result, there are likely to be lower transaction costs. The time lag of the variable suggests that this position may positively influence the decision of an FS to cooperate locally. Another, more speculative, possibility is that these characteristics of the FS might attract local innovators, especially SMEs. A dominant position in the market may signal that the FS enjoys market abilities and owns important brands and labels (Kokko, 1994). As claimed by Teece (1986), innovators need "complementary assets" (e.g. marketing skills, advertisements) in order to profit from their own innovation. This "law" of innovation processes is essential in F\&B innovation (Geroski \& Vlassopulos, 1991). Small local innovators and universities often lack commercial know-how and "complementary assets" to turn their inventions into profitable new products. Therefore, FS which possess these skills and "assets" may be attractive targets for these innovators and universities.

Finally, FS encountering fewer-than-average knowledge obstacles (i_knowlobst) are more likely to build local R\&D cooperation networks; as stated previously, knowledge refers here to both technical and market knowledge.

These results provide support for $\mathrm{H} 2$ (Obstacles to innovation are likely to be a deterrent for local cooperation for innovation). Foreign subsidiaries facing fewer obstacles to innovation than the average F\&B firm have greater 
chances of building local R\&D networks. In that connection, what is also noteworthy is that these FS are not necessarily innovation-intensive companies. The four variables denoting obstacles to innovation and i_innovExp correlate very weakly (Appendix 2). The signs of these correlations are negative, meaning that innovation-intensive FS tend to face fewer obstacles to innovation than the average F\&B firm. However, none of the four relationships between the variables are statistically significant.

The coefficients of i_size and i_export are not statistically significant. Having an industrial plant larger than average does not influence whether an FS cooperates locally for innovation. Our results support those of Ebersberger et al. (2011) for European companies operating in low-tech industries. Our results for i_export are in line with those of Andersen (2013), who proposes that knowledge exchanged in networks has a local quality that may be useful in domestic markets but not necessarily in international markets.

\section{Conclusions.}

We have striven to identify the main characteristics of food and beverage foreign subsidiaries engaged in local R\&D cooperation in Spain. Since policymakers seem to believe that FS could make important contributions to the national innovation system (Guimón, 2009), we tested whether subsidiaries enjoying an outstanding technological endowment were likely to cooperate with local partners. We found, however, that subsidiaries more innovation-intensive than the average food and beverage company were not especially interested in R\&D cooperation with local partners, nor were those that hired more R\&D employees than average, or those that sold relatively more new products than average. These results are a departure from cross-sectional studies, which suggest that R\&D-intensive subsidiaries tend to cooperate for innovation (Álvarez \& Cantwell, 2011; Holl \& Rama, 2014; Manolopoulos et al., 2005). Our findings suggest that the technical contribution by food and beverage subsidiaries via R\&D local cooperation might be limited. The possession of substantial economic strength to finance innovation seems the most important feature of food and beverage foreign subsidiaries engaged in R\&D cooperation in Spain; however, these companies are not necessarily innovation-intensive. The appropriability regime in this industry and the ease of imitation may have 
dissuaded highly innovative food and beverages multinationals to cooperate with local partners, and this is especially true when those potential partners are likely to enjoy absorptive capacity. Instead, the cooperation strategy of F\&B multinationals seems to pivot around the financing of local networks of innovators. Our research corroborates previous studies in that highly innovative companies remain unlikely to engage in local R\&D cooperation in traditional industries (Ebersberg et al., 2011). However, our results show another side of the story as yet undisclosed by these studies: in traditional industries in which the host-country has some absorptive capacity and, hence, highly innovative subsidiaries may fear involuntary spillovers of knowledge , MNEs may provide economic and marketing resources to networks of local innovators, although not necessarily state-of-the-art technology. This constitutes one of the contributions of our article towards a theory of cooperation patterns of foreign subsidiaries in traditional industries. Our research confirms that MNEs are not a homogenous group. More sectoral studies are needed to put to test the idea that foreign subsidiaries operating in different sectors may adopt different cooperative strategies

Our research has policy implications. Expectations regarding possible transfers of technology to the host industry may be too optimistic, at least regarding this industry. The research suggests that Spain needs to rely mainly on its own innovative strength, rather than on the presence of foreign companies, for the technological upgrading of its food and beverage industry. Multinational enterprises may contribute funding or complementary assets to local networks of innovators. However, the technological improvement of this industry is more likely to originate from the contribution of technical and scientific institutions (Acosta et al., 2011), and from the strengthening of companies' internal R\&D capabilities, as well as from that of auxiliary industries. This is a crucial consideration, given the current restrictions on public R\&D spending in peripheral European countries and elsewhere. Moreover, policymakers can, specifically, stimulate precompetitive and basic R\&D cooperation between these institutions and domestic firms, on the one hand, and highly innovative foreign subsidiaries, on the other. In the food and beverage industry, this type of collaboration may be more acceptable to innovative foreign companies since it implies fewer risks of involuntary spillovers than 
collaborations that focus on applied R\&D research or product development, and may nevertheless be useful for the upgrading of host-industries. As for managers, our study suggests that the FS needs to maintain a clear vision of what it has to offer to local R\&D partners, not only in terms of technology but also in marketing skills and other innovation-related resources.

Given the importance of inter-sectoral R\&D cooperation in this industry, insufficient development of certain auxiliary industries in the host country may have also played some role in explaining the lack of interest shown by highly innovative subsidiaries in local cooperation. One major limitation of our model arises from the fact that the available data fails to allow us to distinguish between inter-sectoral and within-sector cooperation: neither do they allow us to control for subsectors within the food and beverage industry. The need for further, better data is obvious. A relevant avenue for future research involves the detailed analysis of the types of local partners (universities, suppliers, clients), if any, that are preferred by highly innovative foreign food and beverage subsidiaries for R\&D collaboration. It would be useful to ascertain whether these subsidiaries are more willing to cooperate even in applied research and product development with institutions than they would be with domestic firms, given that institutions are less likely to become their competitors. This analysis could contribute towards providing policy-makers with insights about the types of local partners who, in this industry, have greater chances of entering partnerships with highly innovative foreign subsidiaries. On the other hand, this is a study on a single country, and quantitative studies on other countries are needed in order to corroborate our thesis regarding patterns of local R\&D collaboration of foreign food and beverage subsidiaries. This would certainly improve our understanding of the local cooperative activities of MNEs. 


\section{Table 1}

\section{Results of logistic regression for local R\&D cooperation}

\begin{tabular}{|c|c|c|c|c|c|c|c|c|}
\hline $\begin{array}{l}\text { Random-effects } \\
\text { Group variable }\end{array}$ & $\begin{array}{l}\text { logistic } \\
\text { ident }\end{array}$ & ession & & $\begin{array}{l}\text { Numb } \\
\text { Ranc }\end{array}$ & $\begin{array}{l}\text { er of obs } \\
\text { lom effects }\end{array}$ & $u_{-}$ & & - Gaussian \\
\hline Obs per group: & $\mathrm{mi} \mathrm{n}=$ & 1 & & & & $\begin{array}{l}a \vee g \\
\max \end{array}$ & $\begin{array}{l}= \\
=\end{array}$ & $\begin{array}{r}2.8 \\
4\end{array}$ \\
\hline Log likelihood & $=-35.428$ & & & $\begin{array}{l}\text { Wald } \\
\text { Prob }\end{array}$ & $\begin{array}{l}\operatorname{chi} 2(5) \\
>\operatorname{chi} 2\end{array}$ & & $\begin{array}{l}= \\
=\end{array}$ & $\begin{array}{r}33.30 \\
0.0000\end{array}$ \\
\hline$d \circ m R D C O O p$ & Coef. & Std. Err. & $z$ & $P>|z|$ & [ $95 \%$ & Conf & & |nterva|] \\
\hline $\begin{array}{r}\text { i ownf und } \\
\text { interninfo } \\
i-k n o w l o b s t \\
\text { i_econobst }\end{array}$ & $\begin{array}{r}13.42819 \\
4.402842 \\
-4.258969 \\
-9.504707\end{array}$ & $\begin{array}{l}\text { 3. } 913896 \\
\text { 2. } 308788 \\
\text { 2. } 157062 \\
\text { 2. } 297008\end{array}$ & $\begin{array}{r}3.43 \\
1.91 \\
-1.97 \\
-4.14\end{array}$ & $\begin{array}{l}0.001 \\
0.057 \\
0.048 \\
0.0000\end{array}$ & $\begin{aligned} & 5.757 \\
&-.1222 \\
&-8.486 \\
&-14.00\end{aligned}$ & $\begin{array}{l}7092 \\
2993 \\
6733 \\
0676\end{array}$ & & $\begin{array}{r}21.09928 \\
8.927984 \\
-.031205 \\
-5.002655\end{array}$ \\
\hline $\begin{array}{r}i \text { _compet obst } \\
\text { L } 1 .\end{array}$ & 4.475232 & 2.266168 & -1.97 & 0.048 & -8.91 & 1684 & & -.0336238 \\
\hline cons & 23.09153 & 4.675316 & -4.94 & 0.000 & 32.25 & 5498 & & -13.92808 \\
\hline IInsigzu & 6.007698 & 4739615 & & & & 7875 & & 6.93664 \\
\hline $\begin{array}{r}\text { si g ma } u \\
r \hbar{ }_{0}\end{array}$ & $\begin{array}{r}20.16299 \\
.9919727\end{array}$ & $\begin{array}{l}4.778241 \\
.0037741\end{array}$ & & & $\begin{array}{l}12.67 \\
.9799\end{array}$ & $\begin{array}{l}7175 \\
9231\end{array}$ & & $\begin{array}{r}32.08288 \\
.996814\end{array}$ \\
\hline
\end{tabular}

Likelihood-ratio test of rho=0: chibar $2(01)=56.94$ prob $>=$ chibar $2=0.000$

Notes: (1) Dependent variable: Local R\&D cooperation for innovation (Y/N) (2) Definitions of variables in Appendix 1 . 
Appendix 1. Description of variables

\begin{tabular}{|c|c|c|}
\hline Name (1) & Description & Values \\
\hline \multicolumn{3}{|l|}{$\begin{array}{l}\text { Cooperation variable (dependent } \\
\text { variable) }\end{array}$} \\
\hline Domestic R\&D cooperation domRDcoop & $\begin{array}{l}\text { Have you cooperated for innovation with local } \\
\text { partners in the last two years? }\end{array}$ & $\mathrm{Y} / \mathrm{N}$ \\
\hline \multicolumn{3}{|l|}{ R\&D-related variables } \\
\hline Own resources & $\begin{array}{l}\text { Share of own resources of the focal company } \\
\text { (including credits) in total resources used to finance } \\
\text { internal R\&D } \\
\text { Share as compared to industry average }\end{array}$ & $\begin{array}{l}1=\text { above industry average } \\
0=\text { below industry average }\end{array}$ \\
\hline R\&D personnel & $\begin{array}{l}\text { No. of employees involved in internal R\&D, } \\
\text { including researchers, technicians and auxiliary } \\
\text { personnel }\end{array}$ & Employment \\
\hline i_RDpers & $\begin{array}{l}\text { No. of R\&D employees as compared to industry } \\
\text { average }\end{array}$ & $\begin{array}{l}1=\text { above industry average } \\
0=\text { below industry average }\end{array}$ \\
\hline $\begin{array}{l}\text { New products } \\
\text { i_new }\end{array}$ & $\begin{array}{l}\text { Percentage of products new to the company in total } \\
\text { sales as compared to industry average }\end{array}$ & $\begin{array}{l}\% \\
1=\text { above industry average } \\
0=\text { below industry average }\end{array}$ \\
\hline $\begin{array}{l}\text { Internal information } \\
\text { i_interinfo }\end{array}$ & $\begin{array}{l}\text { Importance of internal sources of information for } \\
\text { innovation; sources include the company and its } \\
\text { business group } \\
\text { The firm attributes more importance to internal } \\
\text { sources than the average food and beverage } \\
\text { company }\end{array}$ & $\begin{array}{l}\text { 1-4 Likert scale } \\
1=\text { Highly important } \\
4 \text { Not used this source of } \\
\text { information } \\
(\mathrm{Y} / \mathrm{N})\end{array}$ \\
\hline \multicolumn{3}{|l|}{$\begin{array}{l}\text { R\&D intensity (as compared to } \\
\text { industry average) }\end{array}$} \\
\hline Internal R\&D expenditures (i_intRDexp) & $\begin{array}{l}\text { Internal expenditure in R\&D over industry average. } \\
\text { Includes personnel, equipment, acquisition of } \\
\text { software, etc. in year previous to survey }\end{array}$ & $\begin{array}{l}1=\text { above industry average } \\
0=\text { below industry average }\end{array}$ \\
\hline External R\&D expenditures (i_extRDexp) & $\begin{array}{l}\text { External expenditure in R\&D over industry average. } \\
\text { Includes personnel, equipment, acquisition of } \\
\text { software, etc. in year previous to survey }\end{array}$ & $\begin{array}{l}1=\text { above industry average } \\
0=\text { below industry average }\end{array}$ \\
\hline
\end{tabular}




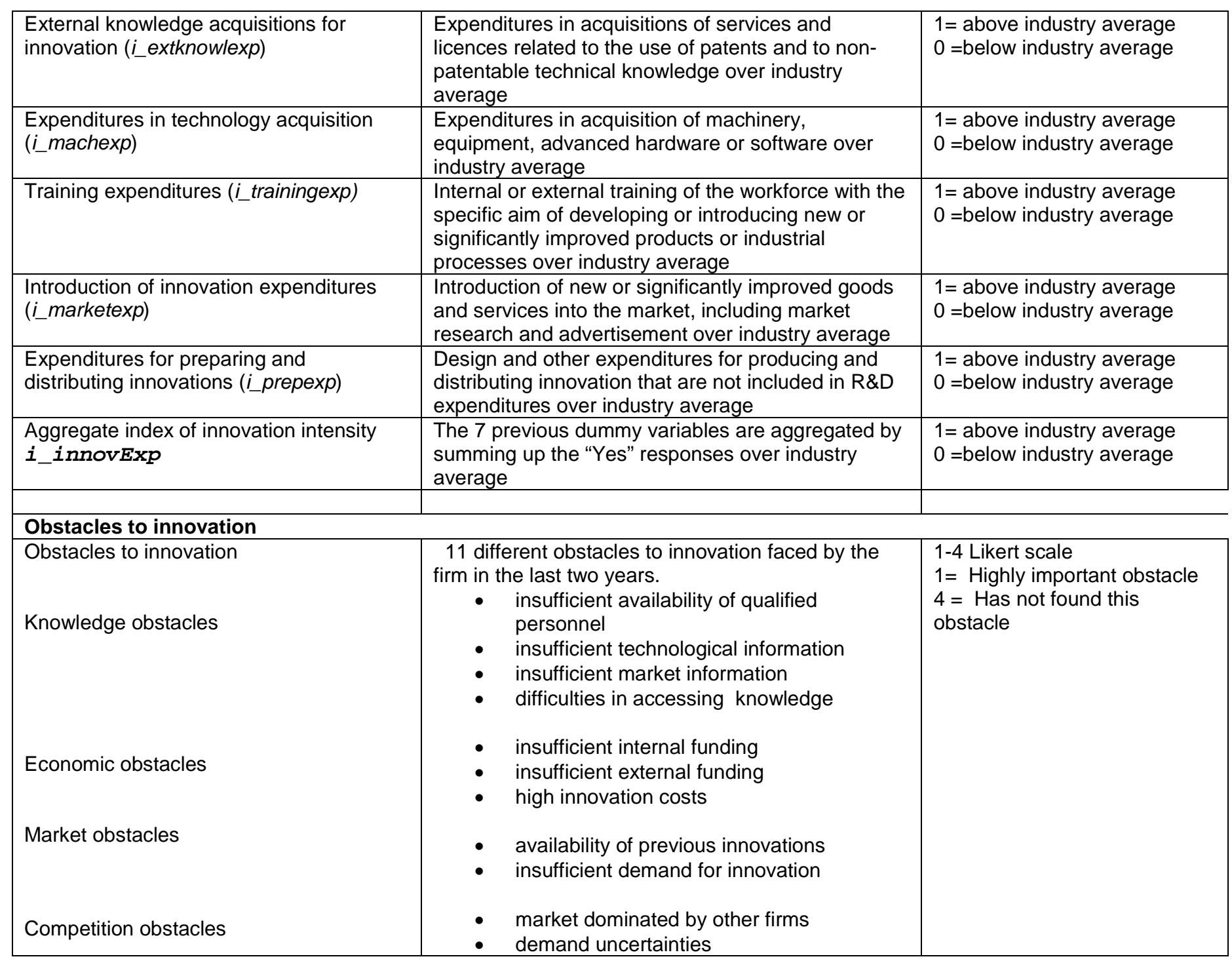




\begin{tabular}{|c|c|c|}
\hline Aggregated obstacle data & $\begin{array}{l}\text { The data on the } 11 \text { obstacles was aggregated and } \\
\text { re-codified through factor analysis into four } \\
\text { categories: technological, economic, market and } \\
\text { competition obstacles }\end{array}$ & $\begin{array}{l}\text { 1-4 Likert scale } \\
1=\text { Highly important obstacle } \\
4=\text { Has never faced this } \\
\text { obstacle }\end{array}$ \\
\hline $\begin{array}{l}\text { i_knowlobst } \\
\text { i_econobst } \\
\text { i_marketobst } \\
\text { i_competobst }\end{array}$ & $\begin{array}{l}\text { Importance of obstacles to innovation as compared } \\
\text { to those encountered by the average F\&B firm }\end{array}$ & $\begin{array}{l}1=\text { The FS faces higher } \\
\text { obstacles than the average } \\
\text { F\&B firm } \\
0=\text { Otherwise }\end{array}$ \\
\hline \multicolumn{3}{|l|}{ Control variables } \\
\hline $\begin{array}{l}\text { Exports } \\
\text { i_export }\end{array}$ & $\begin{array}{l}\text { - Share of sales in foreign countries in total } \\
\text { sales of firm } \\
\text { - Share of sales in foreign countries over } \\
\text { industry average }\end{array}$ & $\begin{array}{l}\% \\
1=\text { above industry average } \\
0=\text { below industry average }\end{array}$ \\
\hline $\begin{array}{l}\text { Size } \\
\text { i_size }\end{array}$ & $\begin{array}{ll}- & \text { Sales } \\
- & \text { Sales over industry average }\end{array}$ & $\begin{array}{l}\text { In } € \\
1=\text { above industry average } \\
0=\text { below industry average }\end{array}$ \\
\hline
\end{tabular}


Appendix 2. Correlation matrix

\begin{tabular}{|c|c|c|c|c|c|c|c|}
\hline | & innovExp & i_RDper & s i_ownfut & i_size & i_export & $t$ i_new $i$ & i_intinfo \\
\hline i_innovEx| & 1.0000 & & & & & & \\
\hline i_RDper| & 0.1373 & 1.0000 & & & & & \\
\hline i_ownfund | & $-\odot .0812$ & $0.4644^{*}$ & 1.0000 & & & & \\
\hline i_size | & 0.1450 & 0.1031 & -0.1480 & 1.0000 & & & \\
\hline i_export | & $\odot .0179$ & $-\odot .0492$ & 0.1076 & $-\odot .1662$ & 1.0000 & & \\
\hline i_new | & 0.1376 & $-\odot .1186$ & 0.0411 & -0.0525 & 0.0041 & 1.0000 & \\
\hline i_intinfo | & 0.0400 & $0.2726^{*}$ & 0.2186 & -0.0965 & $\odot . \odot 761$ & -0.0855 & 1.0000 \\
\hline i_knowobst | & $-\odot .0487$ & $\odot .0417$ & $\odot .0501$ & $-0.3062^{*}$ & $\odot .0747$ & -0.0189 & $-\odot . \odot 479$ \\
\hline i_econobst | & $-\odot .0283$ & 0.0137 & $\odot .0657$ & -0.1730 & 0.0056 & 0.1534 & 0.0037 \\
\hline competobst | & -0.0487 & 0.0417 & 0.2699 * & $-0.3672^{*}$ & 0.1148 & 0.0732 & -0.0148 \\
\hline marketobst & -0.1071 & $-\odot .0262$ & 0.0118 & -0.0657 & $-\odot .0217$ & -0.0139 & -0.0582 \\
\hline
\end{tabular}

| i_knowobts i_econobst i_competobst i_marketobst

\begin{tabular}{r|lcll} 
i_knowobst & 1.0000 & & & \\
i_econobst & $0.2944^{*}$ & 1.0000 & & \\
i_competobts & $0.4174^{*}$ & 0.2355 & 1.0000 & \\
i_marketobts & 0.0663 & -0.0573 & $0.3539^{*}$ & 1.0000
\end{tabular}




\section{References}

Acosta, M., Coronado, D., \& Ferrándiz, E. (2013). Trends in the acquisition of external knowledge for innovation in the food industry. In M. García Martínez (Ed.), Open innovation in the food and beverage industry (pp. 3-24). Oxford: Woodhead Publishing.

Acosta, M., Coronado, D., \& Toribio, R. (2011). The use of scientific knowledge by Spanish agrifood firms. Food Policy, 36, 507-516.

Ahuja, G. (2000). The duality of collaboration: inducements and opportunities in the formation of interfirm linkages. Strategic Management Journal, 21, 317-343.

Alfranca, O., Rama, R., \& von Tunzelmann, N. (2002). A patent analysis of global food and beverage firms: the persistence of innovation. Agribusiness. An International Journal, 18(3), 349-368.

Alfranca, O., Rama, R., \& von Tunzelmann, N. (2004). Combining different brands of in-house knowledge: technological capabilities in food, biotechnology, chemicals and drugs in agri-food multinationals. Science and Public Policy, 31, 227-244.

Álvarez, I. (2011). La colaboración de empresas extranjeras innovadoras en España. Madrid: ICEI- Universidad Complutense de Madrid.

Álvarez, I., \& Cantwell, J. (2011). International integration and mandates of innovative subsidiaries in Spain. International Journal of Institutions and Economies, 3, 415-444.

Anastassopoulos, G., Papanastassiou, M., Pearce, R. D., \& Traill, W. B. (1997). Firm and location. Specific determinants in investment and trade strategies of major multinationals in the food industry in Europe. In S.R.Henneberry (Ed.), Foreign direct investment and processed food trade (pp. 57-78). Oklahoma.

Andersen, K. V. (2013). The problem of embeddedness revisited: Collaboration and market types. Research Policy, 42(1), 139-148.

Bayona-Sáez, C., García-Marco, T., Sánchez-García, M., \& Cruz-Càzares, C. (2013). The impact of open innovation on innovation performance: the case of Spanish agri-food firms. In M. García Martínez (Ed.), Open innovation in the food and beverage industry (pp. 74-94). Oxford: Woodhead Publishing.

Belderbos, R., Carree, M., \& Lokshin, B. (2004). Cooperative R\&D and firm performance. Research Policy, 33(10), 1477-1492.

Cantwell, J. (2009). Location and the Multinational Enterprise. Journal of International Business Studies, 40(1), 35-41.

Cantwell, J., \& lammarino, S. (2000). Multinational corporations and the location of technological innovation in the UK regions. Regional Studies, 34(4), 317-332.

Cantwell, J., \& Janne, O. (2000). Globalization of innovatory capacity: the structure of competence accumulation in European home and host countries. In F. Chesnais, G. Ietto-Gillies \& R. Simonetti (Eds.), European integration and global corporate strategies (pp. 121-177). London-NY: Routledge.

Carboni, O. A. (2013). Heterogeneity in R\&D cooperation: an empirical investigation Structural Change and Economic Dynamics, 25, 48-59.

Caves, R. E. (1996). Multinational enterprise and economic analysis (2nd ed.): Cambridge University Press.

Christensen, J. L., Rama, R., \& von Tunzelmann, N. (1996). Study on Innovation in the European Food Products and Beverages Industry (No. EIMS SPRINT). Brussels: The European Commission.

Cohen, W. M., \& Levinthal, D. A. (1989). Innovation and learning: The two faces of R\&D. Economic Journal, 99, 569-596.

Driffield, N., Love, J., H., \& Yang, Y. (2014). Technology sourcing and reverse productivity spillovers in the multinational enterprise: global or regional phenomenon? British Journal of Management, 25(S1), S24-S41. 
Easton, G. (1992). Industrial networks: a review. In B. Axelsson \& G. Easton (Eds.), Industrial networks. A new view of reality (pp. 3-27). London and N.Y,: Routledge.

Ebersberger, B., Herstad, S. J., Iversen, E., Kirner, E., \& Som, O. (2011). Analysis of innovation drivers and barriers in support of better policies. Economic and market intelligence on innovation. Open innovation in Europe: effects, determinants and policy. Oslo: European Commission. Enterprise and Industry.

Edler, J. (2008). Creative internationalization: widening the perspectives on analysis and policy regarding international R\&D activities. Journal of Technology Transfer, 33, 337-352.

Fernández Sastre, J. (2012). Efectos y determinantes de la cooperación para la innovación tecnológica: un estudio empírico sobre un panel de datos de empresas localizadas en España (Effects and determinants of cooperation for technological innovation: An empirical study on panel data from companies located in Spain), Ph.D. Thesis, Universidad Autónoma de Madrid, Madrid.

Franco, E., \& Quadros, R. (2003). Patterns of technological activities of transnational corporations affiliates in Brazil. Research Evaluation, 12(2), 117-129.

Galizzi, G., \& Venturini, L. (2008). Nature and determinants of product innovation in a competitive environment of changing vertical relationships. In R. Rama (Ed.), Handbook of innovation in the food and drink industry (pp. 51-80). New York and London: Taylor \& Francis Group.

Gallo, A. E. (1995). Are there too many new product introductions in US food marketing? Journal of Food Distribution Research, 26(1), 9-13.

García Martínez, M. (2013a). Open innovation in the food and beverage industry. Oxford: Woodhead Publishing.

García Martínez, M. (2013b). The "want find get manage" (WFGM) framework for open innovation management and its use by Mars, Incorporated. In M. Garcia Martinez (Ed.), Open innovation in the food and beverage industry (pp. 315331). Oxford: Woodhead Publishing.

García Sánchez, A., Molero, J., \& Rama, R. (2015). Are "the best" multinationals cooperating locally for innovation ?. The case of an intermediate country. Science \& Public Policy (SPP), DOI 10.1093/scipol/scv057

Geroski, P., \& Vlassopoulos, T. (1991). The Rise and Fall of a Market Leader: Frozen Foods in the UK. Strategic Management Journal, 12, 467-478.

Gopinath, M., \& Vasavada, U. (1999). Patents, R\&D, and market structure in the U.S.processing industry. Journal of Agricultural and Resource Economics, 24(1), 127-139.

Guimón, J. (2009). Government strategies to attract R\&D-intensive FDI. Journal of Technology Transfer, 34(4), 364-379.

Guimón, J. (2011). Policies to benefit from the globalization of corporate R\&D:An exploratory study for EU countries. Technovation, 31, 77-86.

Guimón, J., \& Salazar-Elena, J. C. (2015). Collaboration in innovation between foreign subsidiaries and local universities: evidence from Spain. Industry and Innovation, 22(6), 445-466.

Hagedoorn, J. (1993). Understanding the rationale of strategic technology partnering: interorganizational modes of cooperation and sectoral differences. Strategic Management Journal, 14(5), 371-385.

Holl, A., \& Rama, R. (2014 ). Foreign subsidiaries and technology sourcing in Spain. Industry and Innovation, 21(1), 43-64.

Ito, B., \& Wakasugi, R. (2007). What factors determine the mode of overseas R\&D by multinationals? Empirical evidence. Research Policy, 36, 1275-1287.

Jongen, W. M. E., \& Meulenberg, M. T. G. (2005). Introduction. In W. M. E. Jongen \& M. T. G. Meulenberg (Eds.), Innovation in agri-food systems. product quality and consumer acceptance (pp. 13-16). The Netherlands: Wageningen Academic Publishers. 
Kokko, A. (1994). Technology, market characteristics, and spillovers. Journal of Development Economics, 43(2), 279-293.

Knell, M., \& Srholec, M. (2005). Innovation cooperation and foreign ownership in the Czech Republic, Norwegian Institute for Studies in Innovation, Research and Education (NIFU-STEP).

Lazzarotti, V., \& Manzini, R. (2013). The tension between traditional innovation strategies and openess: Lindt's controlled open innovation approach. In M. García Martínez (Ed.), Open innovation in the food and beverage industry (pp. 25-38). Oxford: Woodhead Publishing.

López, A. (2008). Determinants of R\&D cooperation: Evidence from Spanish manufacturing firms. International Journal of Industrial Organization, 26, 113136.

Manolopoulos, D., Papanastassiou, M., \& Pearce, R. (2005). Technology sourcing in multinational enterprises and the roles of subsidiaries: An empirical investigation. International Business Review, 14, 249-267.

McCann, P., \& Mudambi, R. (2004). The location behaviour of the multinational enterprise: some analytical issues. Growth and Change, 35(Fall), 491-524.

Miotti, L., \& Sachwald, F. (2003). Co-operative R\&D: why and whith whom? An integrated framework of analysis. Research Policy, 32, 1481-1499.

Molero, J., \& García, A. (2008). The innovative activities of foreign subsidiaries in the Spanish Innovation System: An evaluation of their impact from a sectoral taxonomy approach. Technovation, 28, 739-757.

Moodie, R., Stuckler, D., Monteiro, C., Sheron, N., Neal, B., Thamarangsi, T., et al. (2013). Profits and pandemics: prevention of harmful effects of tobacco, alcohol, and ultra-processed food and drink industries. The Lancet, 381(9867), 670-679.

Mortara, L., \& Minshall, T. (2011). How do large multinational companies implement open innovation? Technovation, 31(10-11), 586-597.

Omta, S. W. F., Fortuin, F. T. M., \& Dijman, N. C. (2014). Open innovation in the food industry: An evidence based guide. Wageningen, The Netherlands: Food Valley NL.

Rama, R. (1996). An empirical study on sources of innovation in the international Food and Beverage industry. Agribusiness: An International Journal, 12, 123-134.

Rama, R., \& Martínez, C. (2013). The changing structure of the global agribusiness sector. In Frank Giarratani, G. J. D. Hewings \& P. McCann (Eds.), Handbook of Economic Geography and Industry Studies (pp. 305-340): Edward Elgar.

Rama, R., \& von Tunzelmann, N. (2008). Empirical studies of innovation in the food and beverage industry. In R. Rama (Ed.), Handbook of innovation in the food and drink industry (pp. 13-49). New York and London: Taylor \& Francis Group.

Rugman, A. E., \& Verbeke, A. (2001). Subsidiary specific advantages in multinational enterprises. Strategic Management Journal, 22, 237-250.

Santamaría, L., Nieto, M. J., \& Barge-Gil, A. (2009). Beyond formal R\&D: Taking advantage of other sources of innovation in low- and medium-technology industries. Research Policy, 38(3), 507-517.

Schmidt, T. (2008). Motives for innovation cooperation? Evidence from the Canadian Survey of Innovation. http://hdl.handle.net/10419/24570, ZEW Discussion Papers no.08-018

Senauer, B., \& Venturini, L. (2005). The globalization of food systems: a conceptual framework and empirical patterns. Minnesota: The Food Industry Center, University of Minnesota

Singh, J. (2007). Asymmetry of Knowledge Spillovers between MNCs and Host Country Firms. Journal of International Business Studies, 38(5), 764-786.

Srholec, M. (2009). Does Foreign Ownership Facilitate Cooperation on Innovation? Firm-level Evidence from the Enlarged European Union European Journal of Development Research, 21, 47-62. 
Srholec, M. (2015). Understanding the diversity of cooperation on innovation across countries: multilevel evidence from Europe. Economics of Innovation and New Technology, 24(1-2), 159-182.

Teece, D. J. (1986). Profiting from technological innovation: Implications for integration, collaboration, licensing and public policy. Research Policy, 15, 285305.

Tepic, M., Omta, S. W. F., \& Fortuin, F. T. M. (2013). Managing co-innovation partnerships: the case of Unilever and its preferred flavour suppliers. In M. García Martínez (Ed.), Open innovation in the food and beverage industry (pp. 254-275). Oxford: Woodhead Publishing.

Tozanli, S. (2005). The rise of global enterprises in the world's food chain. In R. Rama (Ed.), Multinational Agribusinesses (pp. 1-72). N.Y.: Haworth Press Inc.

Trienekeus, J. H., Hagen, J. M., Beulens, A. J. M., \& Omta, S. W. F. (2003). Innovation through (international) food supply chain development: a research agenda. International Food and Agribusiness Management Review, 6(1).

Triguero, Á., Córcoles, D., \& Cuerva, M. C. (2013). Differences in Innovation Between Food and Manufacturing Firms: An Analysis of Persistence. Agribusiness. An International Journal, 29(3), 273-292.

Tripple, M. (2011). Regional innovation systems and knowledge-sourcing activities in traditional industries - evidence from the Vienna food sector. Environment \& Planning A, 43, 1599-1616.

UNCTAD (Ed.). (2001). World Investment Report 2001. Promoting Linkages. New York and Geneva: United Nations Conference on Trade and Development.

Wijnands, J. H. M., Bremmers, H. J., van der Meulen, B. M. J., \& Poppe, K. J. (2008). An Economic and Legal Assessment of the EU Food Industry's Competitiveness. Agribusiness. An International Journal, 24(4), 417-439.

Williamson, O. E. (1985). The economic institutions of capitalism. New York and London: The Free Press.

\footnotetext{
${ }^{1}$ Also referred to in the literature and in this article as R\&D cooperation or as collaboration for innovation.

${ }^{2}$ NACE rev 2, Manufacturing Statistics,

http://epp.eurostat.ec.europa.eu/statistics explained/index.php/Manufacturing statistics, October 2014

${ }^{3}$ OECD statistics on globalization: Inward activity of multinationals - share in national total, from http://stats.oecd.org/index.aspx, as of February 2010 (data for 2007).

${ }^{4}$ OECD statistics on globalization: Inward activity of multinationals http://stats.oecd.org/index.aspx, as of October 2014.

${ }^{5}$ OECD statistics on globalization: Inward activity of multinationals http://stats.oecd.org/index.aspx, as of October 2014.

${ }^{6}$ http://datainvex.comercio.es/principal invex.aspx Datainvex, Estadísticas de inversión extranjera en España, Ministerio de Economía y Competitividad, Gobierno de España as of October 2014.
} 